\title{
RELATIONSHIPS OF USING SOCIAL MEDIA ONLINE TO LEARNING ENGLISH AT THE ENGLISH PROGRAM, STBA YAPARI-ABA BANDUNG
}

\author{
Vindy Melliany Puspa \\ Sekolah Tinggi Bahasa Asing YAPARI-ABA \\ Jl. Cihampelas No.194, Bandung 40131, Indonesia \\ vindymellianypuspa85@gmail.com
}

\begin{abstract}
The purpose of this research was to get the information on the frequency of using social media, identify the types of social media features, and prove the relationship between the frequency of using social media in English learning. This research used quantitative approach. Data were collected through a questionnaire distributed on a propotional random sampling that were analyzed using descriptive statistics. The respondents were 100 students, taken from several classes of regular students in Bachelor Degree in Semester VI and VIII of English program in STBA Yapari-ABA Bandung. The results show that most respondents have more than three social media accounts (71\%). Youtube is the site that the most influential respondents (53\%). The most useful social media feature is 'sharing' (54\%) while the most frequently used part of the sentence is 'phrase' (42\%). The most beneficial language ability is vocabulary (31\%). There are other descriptive data describing the frequency of various English related activities in the use of respondents' social media. In addition, it is evident that there is a positive correlation, although its correlation value is very weak (Spearman rho: 0,098) between the frequency of social media usage with the acquisition of English indicated by the GPA.
\end{abstract}

Keywords: social media usage, English learning, English acquisition

\section{INTRODUCTION}

In general, social media is a site or application that allows users to create and share content and also participate in online networking. According to Kalasi (2014) defines social networking as an online computer network where people can relate and interact with it virtually. Social networks can also be called virtual communities. Ashley (2003) has stated that social media tools are divided into two with synchronized time and unsynchronized time. Social media with synchronized time can display communications simultaneously or at the same time with different places so as to offer spontaneous reaction to its users (twitter, skype, etc.), while social media with unsynchronized time is users communicate at different times and different places (e-mail, blog, etc.). According to Obar and Wildman (2015), some common features are found in social media. They are; (1) social media is generally based on internet applications Web 2.0, (2) user-generated contents such as comments, posts, statuses, likes, uploads of photos or videos become what keep social media alive, (3) individuals or groups can create user profiles within a boundary of a social media service so that this user profile becomes the essential of social media, (4) social media facilitates the development of online social networks by connecting user profiles with individuals or other groups.

The problems of this research are; (1) Wshat types of sites are used by students? (2) How many accounts does each student have? (3) What sites do students consider to have a major impact on English acquisition? (4) Which sites are most visited by students? (5) What features are most helpful to students in the acquisition English? (6) What parts of the sentences are most often used by students 
in social media? (7) How frequent is the use of various social media features within supporting the acquisition of English? (8) Does the frequency level of social media use affect the level of English language acquisition for social media users? (9) Does the frequency of use of social media affect English learning rate with GPA value indicator?

Kaplan and Haenlein (2010) have classified social media based on low or high social presence/media richness and self-presentation/self-disclosure on the social media platform that can be seen in Table 1. Based on Table 1, low social media presence is Blogs, medium presence includes social networking sites such as Facebook, and high social media presence is virtual social worlds, for example, Second Life. Moreover, low self-disclosure for collaborative projects is Wikipedia, the medium content community is Youtube, and the virtual game world is World of Warcrafts.

Table 1 Classification of Social Media Based on Social Presence/Media Richness and Self Presentation/Self-disclosure

\begin{tabular}{|c|c|c|c|c|}
\hline & \multicolumn{3}{|c|}{ Social Presence/Media Richness } \\
\hline & & Low & Medium & High \\
\hline Self- & High & $\begin{array}{l}\text { Blogs (e.g. Blogger, } \\
\text { blogspot) }\end{array}$ & $\begin{array}{l}\text { Social networking sites } \\
\text { (e.g. Facebook) }\end{array}$ & $\begin{array}{l}\text { Virtual social worlds (e.g. } \\
\text { Second Life) }\end{array}$ \\
\hline $\begin{array}{l}\text { Sentation/Self- } \\
\text { disclosure }\end{array}$ & low & $\begin{array}{l}\text { Collaborative projects (e.g. } \\
\text { Wikipedia) }\end{array}$ & $\begin{array}{l}\text { Content communities } \\
\text { (e.g. Youtube) }\end{array}$ & $\begin{array}{l}\text { Virtual game worlds (e.g. } \\
\text { World of Warcrafts) }\end{array}$ \\
\hline
\end{tabular}

The Ministry of Communications and Informatics has said that internet users in Indonesia currently reach 63 million people. Of that number, 95\% of them use the internet to access social networks. The most widely accessed social network sites are Facebook and Twitter. Indonesia is ranked as the 4th largest Facebook user after USA, Brazil, and India. At first, Mark Zuckerberg's created a Facebook page is not intended for education, but for social relationships and pleasure. This is stated in a statement that the application to connect and share, "...create greater understanding and connection. Facebook promotes openness and transparency by giving individuals greater power to share and connect..." (www.facebook.com/principles.php). Twitter has 19,5 million users in Indonesia out of a total of 500 million global users, Path with a total of 700.000 users in Indonesia, Line has 10 million users, Google+ has 3,4 million users, and Linkedin has 1 million users (Kemenkominfo, 2013). Statistics company from Germany which is located at www.statista.com has released social network user data for some countries which can be seen in Figure 1. Based on Figure 1, China is the highest number of users social networks while Mexico is the lowest number of users social networks, and Indonesia is in the fifth position in the world.

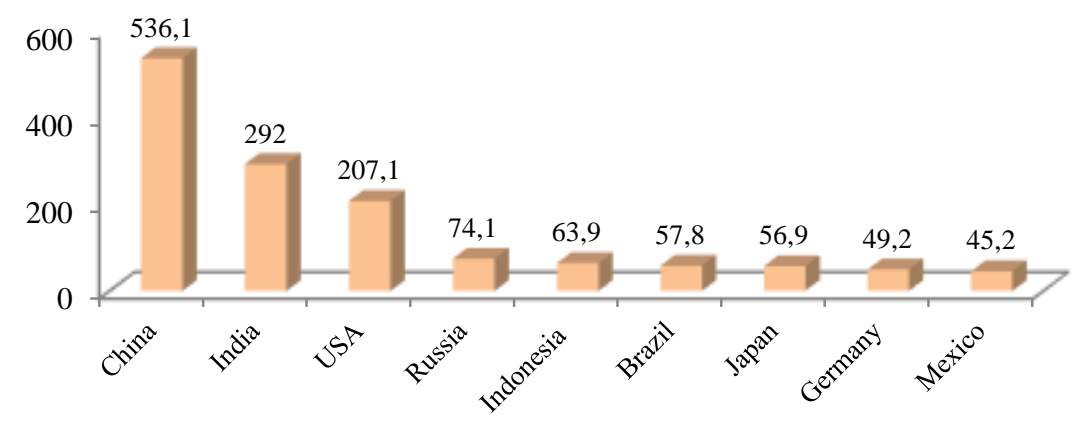

Figure 1 Number of Users of Social Networks

in Several Large Population Countries in 2016 (In Million People)

(Source: https://www.statista.com/statistics/278341/number-of-social-network-users-in-selected-countries/) 
Sitthirak (2013) has stated that social media can create a community where teachers and students can communicate not directly or face-to-face in the classroom. The influence of social media in teaching and learning is illustrated by the teaching-learning style, teacher-student rules, and the influence of the point of view. While Kalasi (2014) has argued that the language educators today begin to teach not only grammar rules, but rather try to help students gain knowledge by discussing in a community. This can be achieved by creating meaningful interactions both inside and outside the classroom and also providing access to an online environment where students can communicate internationally through social media.

Dhanya (2016) describes some of the advantages of using Facebook in English education, they are; (1) createing a closed group, (2) creating an open group for larger participants, such as courses or language programs, (3) creating a poll to obtain reciprocal information, (4) creating questionnaires to obtain information on student preferences and interests, (5) uploading the subject matter so that it is available forever and can be corrected, (6) upgrading materials using notification facilities so students will be informed of the change of the latest information.

In 2007, the British Council has researched how the internet affects the learning style of English from young people around the world. $69 \%$ of people feel effective learning when interacting informally. The results of this study suggest that many students can learn well with their friends or family. Something learned from a loved one will be more memorable in life than something learned while in class (Dalton, 2009). Research on the impact of English learning programs on Facebook in 60 primary school students generally shows a better attitude than traditional classroom learning. This is because the students get new experiences in learning. Achievement of learning in study groups using Facebook also shows the better results than traditional (Wang \& Chen, 2013).

Monica-Ariana and Anamaria-Mirabela (2014) have proved that no significant difference between students who are grouped learning to use Facebook and control groups during vocabulary learning at 127 students from the Faculty of Economic Science, University of Oradea. While Kamnoetsin (2014) has examined the behavior of writing in English on Facebook and in the academic class. The research data shows that students make verb-tense errors in writing in the academic environment compares to Facebook. While punctuation and spacing problems more often do not occur in writing in the academic environment than in Facebook.

Research conducted by Lubis et al. (2011) provides an overview of the relationship between the time of using Facebook with the value of CGPA (Cumulative Grade Point Average). This study shows that there is no significant relationship between the time spends on the using Facebook with CGPA students, so it can be concluded that the achievement of these values cannot be associated with the time of using Facebook. Kabilan, Ahmad, and Abidin (2010) have stated that a tendency to show that the use of online media Facebook can improve the learning of English. The trend is related to the frequent use of English when interacting and their agreement to the improvement of various English learning on Facebook. While Bicen, Sadıkoglu, and Sadıkoglu (2014) have suggested that there are indications that students do learn a foreign language through social media continued to show concern or anxiety when communicating with others. But there are also positive effects of learning through social media that they follow a teacher of foreign languages and use different facilities to improve their speaking. In addition, students also use automatic translation to help reading the news in a foreign language.

Research on the effects of media discussion Facebook as grammar and writing at the lowintermediate EFL students shows that there are significant differences between the average value between the pre-test and post-test students. The pre-test is given before the discussion that is conducted to determine the scientific background of students on grammar and writing, while the posttest is performed after the discussion is completed to determine the improvement of grammar and writing abilities of students (Suthiwartnarueput \& Wasanasomsithi, 2012). Wu and Wu (2011) have 
published a study on the influence of blogs on learning English. The data of this study indicate that many students have positive perceptions to use the blog as a medium of learning English in groups because it has an environment to interact and discuss with others. In addition, students also feel helpful in the ability to write and read in English.

\section{METHODS}

The population of research are undergraduate students of English Semester VI and VIII STBA YAPARI-ABA Bandung. Sample data are taken from 90 respondents who will be questioned about gender, semester, year of entry, and some follow-up questions related to social media. The research is conducted in May-July 2017 in the campus of STBA YAPARI-ABA Bandung.

This research uses quantitative approach. Data are collected through a questionnaire distributed on a proportional random sampling. Data are analyzed using descriptive statistics that are taken from several classes of regular students in Bachelor Degree in Semester VI and VIII of English. The total sample of 100 students.

To obtain information, a questionnaire consisting of 17 questions (see Appendices 1 Questionaire). The questions are divided into two parts of A with 6 questions and answers to personal opinions in the form of multiple choice and part B with 11 questions and answers to the frequency scale in the form of frequent things to do. The frequency is divided into four categories; 1-5 times per week, 6-10 times per week, 10-15 times per week, $>15$ times per week. The choice of questions about social media accounts owned by respondents is limited only to the most widely used platform-specific social media in Indonesia; Facebook, Twitter, Linkedin, Youtube, Google +, Blogg, and Wordpress.

There are two parts of analysis in this research that use descriptive statistic. The unit of analysis used is individual students. All data are analyzed using Microsoft Excel 2010 software. The data of respondents from answered questions are presented with descriptive statistics using graphs so that it would show the respondent profile and frequency of the most frequently chosen answers. The next analysis is to find a correlation between the frequency of social media usage and the acquisition of English indicated by GPA. The frequency usage data from question B is converted to a scale form then compared to the GPA value using the Spearman test. This test template is built by Peixoto and Montanher (2013). Illustration of the calculation can be seen in Table 2.

Table 2 Examples of the Use of Frequency Conversion into the Frequency Scale for Each Respondent (Three Respondent Data)

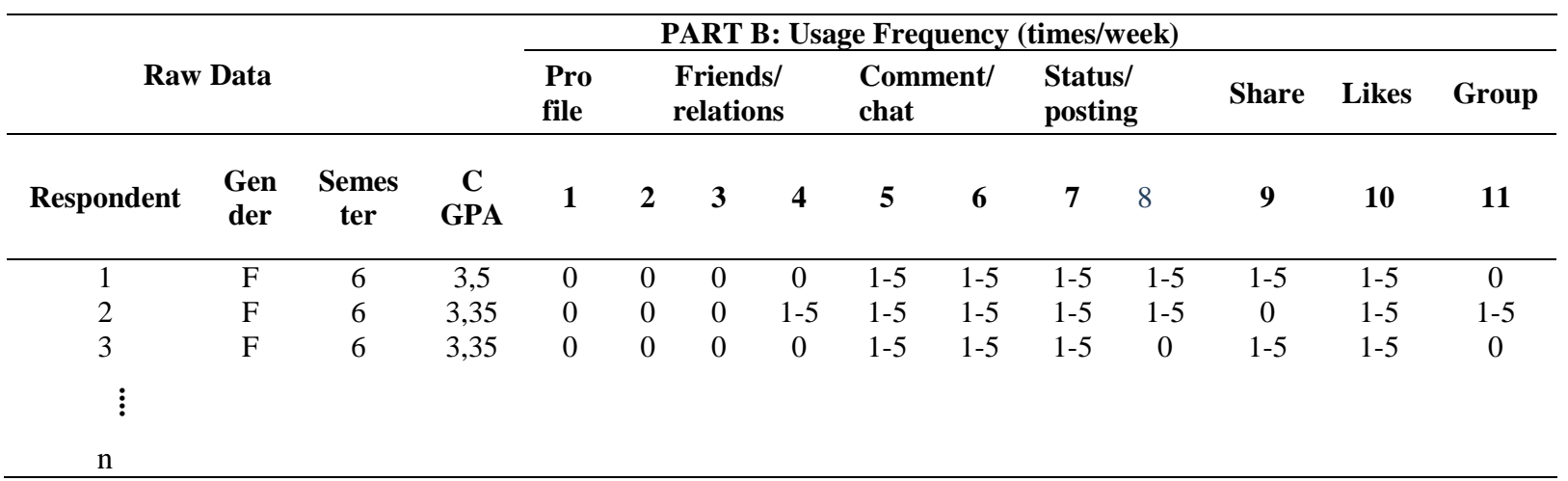


Table 2 Examples of the Use of Frequency Conversion

into the Frequency Scale for Each Respondent (Three Respondent Data) (Continued)

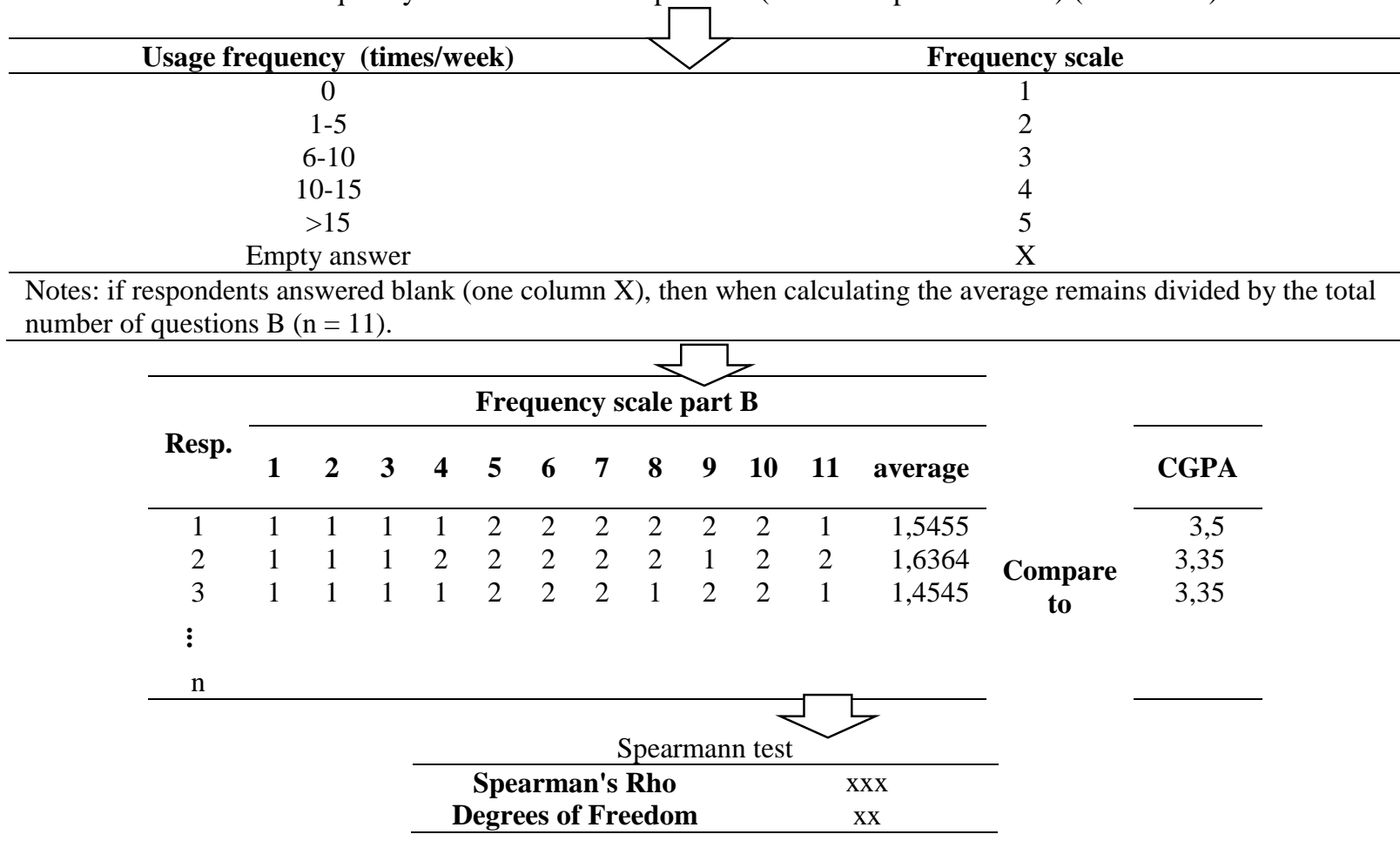

\section{RESULTS AND DISCUSSIONS}

Respondents in this research are the undergraduate students of English, Semester VI and VIII in STBA YAPARI-ABA, Bandung, Indonesia. It is obtained from the total respondents as much as 67 $\%$ of female and $33 \%$ of men. The percentage of respondent's semester is $44 \%$ in the eighth semester and $56 \%$ in the sixth semester that can be seen in Figure 2. The number of respondents who do not answer the question completely is 16 people scattered in part A or part B (see Appendices: Questionaire). Based on the Figure 2, the biggest percentage of student who become respondents is female $67 \%$.

Gender

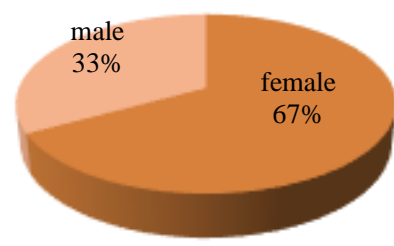

Semester

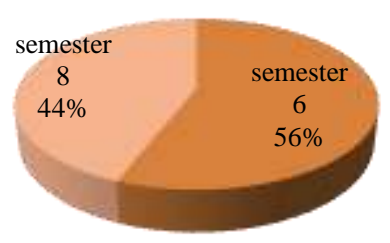

Figure 2 The Percentage of Student Gender and the Level of Semester of English Students who Become Respondents

The distribution of respondent's GPA score has an average value of 3,18 with median 3,2. The lowest student GPA score is 2,22 and the greatest value is 3,89 . Some students do not complete the GPA score until behind the comma because they forget or another cause. While the distribution of these values can be seen in Figure 3. 


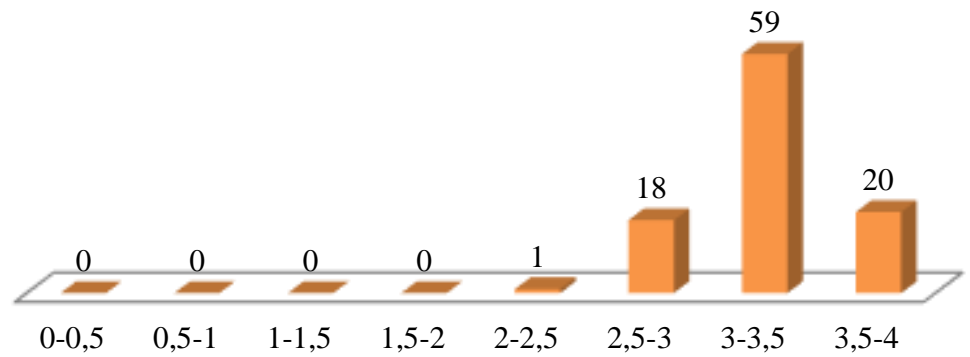

Figure 3 Distribution of GPA Score of English Students who Become Respondents

The use of social media by students is described through several aspects; the type of site that is used, the number of accounts are used, the most visited sites and other questions according to the questions in section A. The various graphs of the general use of social media and its explanations can be seen in the following discussion.

Figure 4, in general, shows that the majority of respondents have several social media sites. Facebook is a site owned by the most respondents. As many as $81 \%$ of respondents have this site, followed by Twitter and Youtube each owned by $68 \%$ of respondents, then Google+ is owned by $67 \%$ of respondents, and Bloggers by $47 \%$, while Linkedin and Wordpress are only owned by $7 \%$ and $5 \%$. Kay et al. (2014) have suggested that the most social networking sites owned by respondents are Facebook, Google+, and Twitter.

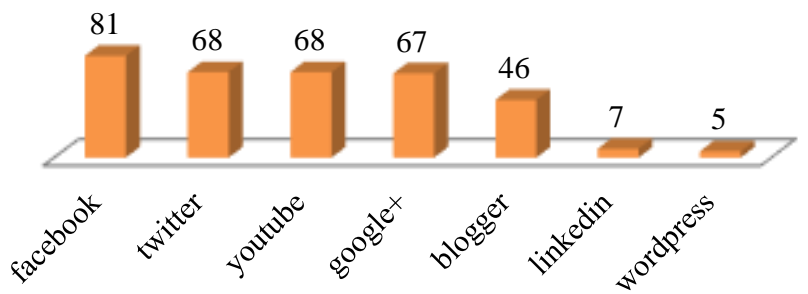

Figure 4 The Most Respondent's Social Media Accounts (in percent) - A1 Question

Figure 5 can be described that the majority of respondents have more than one account. Respondents who have one account are only $9 \%$, two accounts are $17 \%$, six accounts are $2 \%$, seven accounts are $1 \%$, while more than $50 \%$ have accounts between three to five accounts, with details of three accounts are $24 \%$, four accounts are $27 \%$ (highest), and five accounts are $20 \%$.

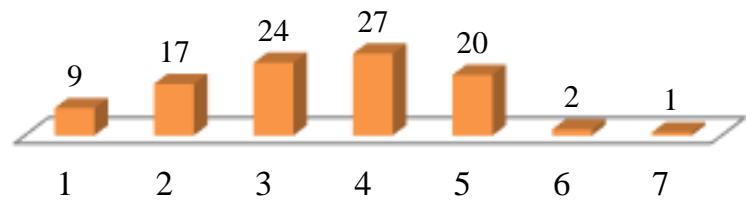

Figure 5 Distribution of the Number of Social Media Accounts Owned by the Respondent (A1 Question)

In Figure 6, Youtube shows the first rank as the site that gives the most influence in the acquisition of English as much as $67 \%$. This is because Youtube is a video sharing platform that has video content that is very helpful in learning listening and speaking. Li (2017) has revealed the same 
findings that Youtube becomes the most famous site for learning English daily by $36 \%$ that is compared to Facebook (21\%), Whatsapp (20\%), Instagram (14\%), and Wiki ( 12\%). Linkedin is ranked last as the most influential website in the acquisition of English because the site is more aimed

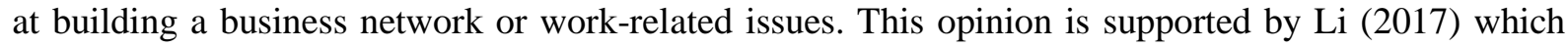
shows Linkedin ranks as the lowest (mean 1,24) as a social media site that is not used for learning English.

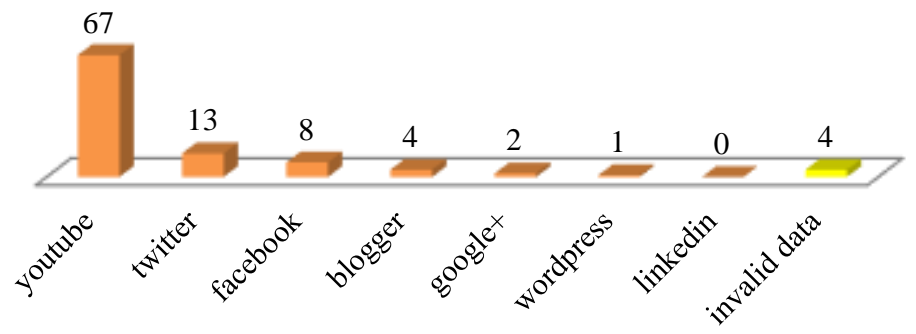

Figure 6 Social Media Sites that have the Greatest Impact on the Acquisition of the Respondent's English (A2 Question)

Youtube also ranks first as the most visited site as seen in Figure 7. The high frequency of visits this site relates to the benefits obtained by respondents and Youtube presents a moving image that is more interactive than the choice of other social media sites. Thurairaj et al. (2015) provide other data on social media sites about social networking sites are most often selected, ie, sequentially up $99,2 \%$, Google $+36,4 \%$, and Twitter $24,2 \%$ with respondents as many as 236 people.

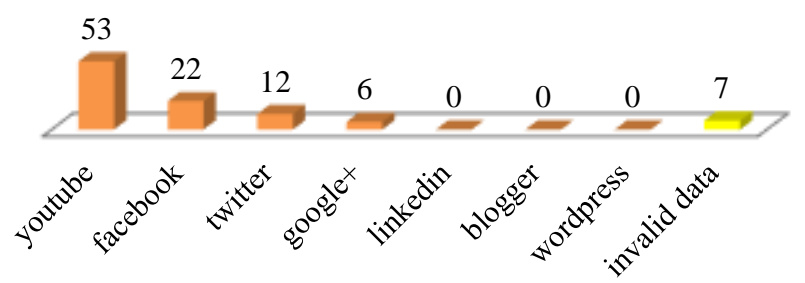

Figure 7 The Most Visited Social Media Sites by Respondents (A3 Question)

'Sharing' is a social media site facility that is considered most helpful in the acquisition of English language as much as $54 \%$. This is because this feature allows respondents to read news or notes in English that can be either their own writing or links to other sites. The next sequence is the 'comment' chosen because it is interactive and dialogical then followed by 'friends' and 'profile'.

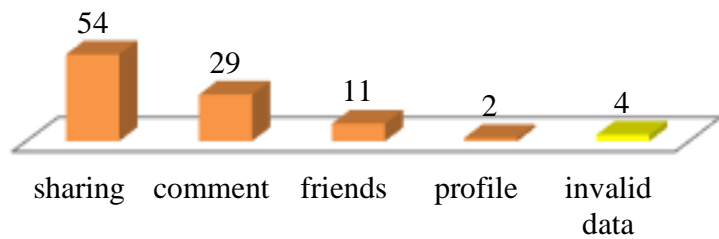

Figure 8 Social Media Site Facilities that are Most Helpful in the Process of Obtaining English (A4 Question) 
In Figure 9, the data obtained as much as $42 \%$ choose phrase (the group of words that form a meaning) as the most used word form when in conversation or writing on social media sites. This may be due to the more flexible phrase inserted into Indonesian sentences in everyday dialogue that is compared to only single words or clauses that require subjects and verbs.

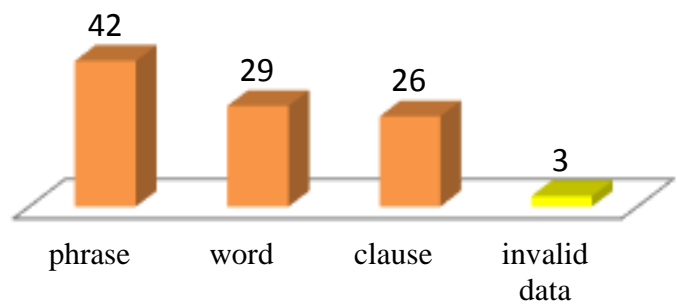

Figure 9 The Most Commonly Used Word Form in Social Media Sites (A5 Question)

The addition of vocabulary wealth makes the most proficiency of language. That is $31 \%$ of vocabulary wealth, then followed by listening $(23 \%)$, and writing $(18 \%)$. When reading or hearing in social media, students can absorb vocabulary that has not been recognized easily because it will unconsciously find out its meaning to understand the reading material. Listening ability by itself will be honed when interacting using video sharing sites, and writing skills used when expressing something in the form of status or comments on social media sites. The findings from the data in Figure 10 are also in line with the Monica-Ariana \& Anamaria-Mirabela's (2014) research that stated the test group exposed to Facebook exposure clearly demonstrates a significant increase in vocabulary knowledge.

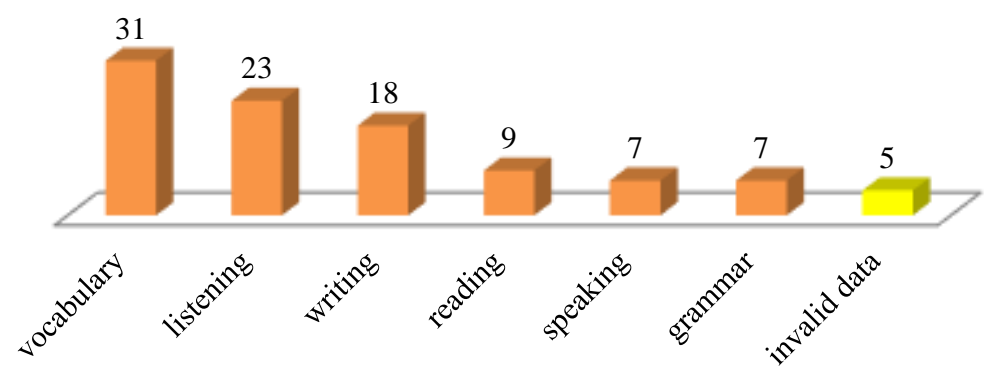

Figure 10 The Most Beneficial Language Skills when Using Social Media Sites (A6 Question)

In addition, learning new vocabulary in a social media site environment provides a condition without correction than traditional learning to provide better vocabulary memories. This is evidenced by Nikbakht (2015) that have suggested the acceptance of vocabulary learning has traditionally provided higher levels of stress (mean 3,5) and learning vocabulary from social media sites provides longer memory (mean 3,67 ) rank from strongly disagree (1) to strongly agree (5).

Table 3 shows various answers to the frequency of using social media by English students listed in question $\mathrm{B}$. 
Table 3 The Answer Frequency Selected Respondents from Question Part B

\begin{tabular}{|c|c|c|c|c|c|c|c|c|c|}
\hline \multirow{2}{*}{ Feature } & \multirow{2}{*}{ No } & \multirow{2}{*}{ Questions } & \multicolumn{5}{|c|}{ Frequency (times per week) } & \multirow{2}{*}{ total } & \multirow{2}{*}{$\begin{array}{c}\text { invalid } \\
\text { data }\end{array}$} \\
\hline & & & $\mathbf{0}$ & $1-5$ & 6-10 & 10-15 & $>15$ & & \\
\hline Profile & $\mathrm{B} 1$ & $\begin{array}{l}\text { How often do you manage your } \\
\text { personal profile with English words } \\
\text { or phrases? }\end{array}$ & 32 & 47 & 10 & 6 & 0 & 95 & 5 \\
\hline \multirow[t]{3}{*}{$\begin{array}{l}\text { Friends/ } \\
\text { Relations }\end{array}$} & B2 & $\begin{array}{l}\text { How often do you add (add) or add } \\
\text { overseas friends who use English } \\
\text { on social networks? }\end{array}$ & 54 & 38 & 2 & 4 & 0 & 98 & 2 \\
\hline & B3 & $\begin{array}{l}\text { How often do you communicate } \\
\text { verbally (video call) with overseas } \\
\text { friends using English? }\end{array}$ & 78 & 15 & 2 & 1 & 0 & 96 & 4 \\
\hline & B4 & $\begin{array}{l}\text { How often do you communicate in } \\
\text { writing (chat or comment) with } \\
\text { overseas friends using English? }\end{array}$ & 31 & 41 & 11 & 6 & 0 & 89 & 11 \\
\hline \multirow[t]{2}{*}{$\begin{array}{l}\text { Commm } \\
\text { ent/Chat }\end{array}$} & B5 & $\begin{array}{l}\text { How often do you use English in a } \\
\text { conversation while chatting or } \\
\text { writing a comment with anyone? }\end{array}$ & 4 & 48 & 25 & 5 & 0 & 82 & 18 \\
\hline & B6 & $\begin{array}{l}\text { How often do you add English } \\
\text { words in an Indonesian-language } \\
\text { conversation on social networking } \\
\text { sites? }\end{array}$ & 10 & 51 & 18 & 11 & 0 & 90 & 10 \\
\hline \multirow[t]{2}{*}{$\begin{array}{l}\text { Status/ } \\
\text { Posting }\end{array}$} & B7 & $\begin{array}{l}\text { How often do you write in your } \\
\text { own account (in the form of status, } \\
\text { tweets, notes, etc.) in English? }\end{array}$ & 16 & 54 & 12 & 11 & 0 & 93 & 7 \\
\hline & B8 & $\begin{array}{l}\text { How often do you add English } \\
\text { words in an Indonesian language } \\
\text { status on social media sites? }\end{array}$ & 23 & 48 & 18 & 6 & 0 & 95 & 5 \\
\hline Share & B9 & $\begin{array}{l}\text { How often do you share things } \\
\text { (news, status, notes etc.) in English } \\
\text { on social media sites? }\end{array}$ & 20 & 45 & 16 & 8 & 0 & 89 & 11 \\
\hline Likes & B10 & $\begin{array}{l}\text { How often do you like things about } \\
\text { English course instructions/courses } \\
\text { / methods on social media sites? }\end{array}$ & 21 & 45 & 25 & 4 & 0 & 95 & 5 \\
\hline Group & B11 & $\begin{array}{l}\text { How often do you follow } \\
\text { groups/discussion groups that use } \\
\text { or learn English on social media } \\
\text { sites? }\end{array}$ & 44 & 38 & 14 & 2 & 0 & 98 & 2 \\
\hline
\end{tabular}

Each social media must provide an identification facility that describes the owner of the account is a personal profile that reflects its identity in cyberspace. Insertion with English words in personal profile data can be a feature of learning English in social media, for example in writing work or the motto of life. The data in section B1 Table 3 shows that almost half of respondents change or manage their profile data in English as much as 1-5 times per week.

In addition to profiles, the friendship facility is becoming one of the hallmarks of social media sites. Interwoven friendships in addition to local friends who speak the same language provide opportunities to train the ability to communicate English. Section B2 Table 3 shows that respondents rarely add or add as friends who come from abroad that are 0 and 1-5 times per week. This tendency is possible because the general purpose of social media sites is to establish communication with friends who have been known but apart distance. Another trend indicated by B3 and B4 suggest that respondents prefer to communicate in writing via chat or comment rather than verbally using English if they have overseas friends. Graphs B5 and B6 provide information that the full use of English in communication with anyone or the insertion of English words in the local language has the largest 
frequency of 1-5 times per week. This frequency describes how often a person in general when confidently uses his ability to speak English even in unnecessary conditions when dialogue with local friends.

Social media sites can also serve as a container of respondent expressions that can be status, twit, notes, or other. This writing ability can also be used as an indicator of learning English. Data on B7 and B8 in Table 3 is an illustration of the use of English in the written phrase in social media. Most respondents admitted 1-5 times per week writing in English in their own account and inserted English words in the Indonesian language. This result is similar to the frequency tendency of using or inserting English in the comment feature. The frequency of sharing information on a subject using English and liking things about English language learning on social media sites is mostly at 1-5 times per week which can be seen in sections B9 and B10. Different tendencies are found in B11 that presents most respondents answering 0 times per week and then followed 1-5 times per week when attending a special English-language discussion group. This result is consistent with the fact that there are rare English language groups in social media except those organized by educational institutions or teachers in particular.

There are two variables used in examining the effect of the frequency of social media usage on the acquisition of English. These variables are the average variables of the social media usage frequency scale with the English language and the GPA value variables. The average data of the frequency scale of social media usage is obtained from the scaling of the frequency of question B then the scale is averaged for each respondent. The general assumption used is that if more and more respondents use English in social media then the higher the value of the GPA that can be seen in Table 4.

Table 4 The Average Data on the Frequency Scale of Social Media Use with English and the Respondent's GPA Score

\begin{tabular}{lcl}
\hline No. & Average frequency scale & CGPA \\
\hline 1 & 1,545 & 3,5 \\
2 & 1,636 & 3,35 \\
3 & 1,455 & 3,35 \\
4 & 2,909 & 2,99 \\
5 & 3,273 & 3,1 \\
6 & 1,727 & 3 \\
7 & 3,364 & 3 \\
8 & 1,364 & 2,9 \\
9 & 1,727 & 2,6 \\
10 & 2,364 & 3,2 \\
11 & 2,727 & 3 \\
12 & 1,636 & 3,5 \\
13 & 1,727 & 3,2 \\
14 & 1,636 & 3,3 \\
15 & 2,727 & 3 \\
16 & 1,909 & 3,5 \\
17 & 2,364 & 3 \\
18 & 1,455 & 2,75 \\
19 & 1,727 & 2,6 \\
20 & 1,727 & 3 \\
21 & 1,818 & 3,3 \\
22 & 1 & 3,42 \\
23 & 1,727 & 3 \\
24 & 2,909 & 2,58 \\
25 & 2 & 3,56 \\
\hline
\end{tabular}

\begin{tabular}{lcl}
\hline No. & Average frequency scale & CGPA \\
\hline 26 & 1,273 & 3 \\
27 & 1,364 & 2,87 \\
28 & 2,727 & 3,3 \\
29 & 1,9 & 3 \\
30 & 2,182 & 3,5 \\
31 & 1,636 & 3,07 \\
32 & 1,455 & 2,6 \\
33 & 2,273 & 2,5 \\
34 & 2,909 & 3,7 \\
35 & 1,818 & 3,2 \\
36 & 1,636 & 3,1 \\
37 & 2,636 & 3,89 \\
38 & 1,727 & 3,4 \\
39 & 3,364 & 3,6 \\
40 & 1,909 & 3,56 \\
41 & 1,091 & 3,1 \\
42 & 1,273 & 3,25 \\
43 & 2,9 & 3 \\
44 & 2,182 & 3,8 \\
45 & 3,455 & 3,16 \\
46 & 2,364 & 2,76 \\
47 & 2,182 & 3,66 \\
48 & 2,364 & 3,8 \\
49 & 2,182 & 3 \\
50 & 2,727 & 3 \\
\hline
\end{tabular}


Table 4 The Average Data on the Frequency Scale of Social Media Use with English and the Respondent's GPA Score (Continued)

\begin{tabular}{lcl}
\hline No. & Average frequency scale & CGPA \\
\hline 51 & 3,182 & 3,51 \\
52 & 1,909 & 3 \\
53 & 2,091 & 3,5 \\
54 & 2,182 & 3,2 \\
55 & 1,909 & 3,4 \\
56 & 1,455 & 2,8 \\
57 & 2,364 & 2,84 \\
58 & 2,273 & 3,21 \\
59 & 2,909 & 3,4 \\
60 & 2,818 & 3,2 \\
61 & 1,636 & 3 \\
62 & 1,7 & 3,08 \\
63 & 1,909 & 3,22 \\
64 & 2,5 & 3,28 \\
65 & 2,364 & 2,93 \\
66 & 1,455 & 2,64 \\
67 & 2,727 & 3,49 \\
68 & 1,909 & 3,47 \\
69 & 1,364 & 3,8 \\
70 & 1,909 & 3,65 \\
71 & 2,091 & 3,13 \\
72 & 2,273 & 3,6 \\
73 & 2,364 & 2,97 \\
74 & 3,545 & 3,67 \\
\hline & & \\
\hline
\end{tabular}

\begin{tabular}{lcl}
\hline No. & Average frequency scale & CGPA \\
\hline 75 & 2,818 & 3 \\
76 & 1,818 & 2,75 \\
77 & 1,909 & 3 \\
78 & 2,091 & 3,11 \\
79 & 3,636 & 3 \\
80 & 1,455 & 3,54 \\
81 & 3,091 & 3,2 \\
82 & 3,455 & 3,47 \\
83 & 2,182 & 2,75 \\
84 & 2,091 & 2,73 \\
85 & 1,818 & 3,4 \\
86 & 1,545 & 3,3 \\
87 & 3,182 & 2,22 \\
88 & 1,545 & 3,25 \\
89 & 2,818 & 3,11 \\
90 & 2,909 & 3,45 \\
91 & 2,818 & 3,44 \\
92 & 1,727 & 3,36 \\
93 & 2,636 & 3,4 \\
94 & 1,909 & 3,2 \\
95 & 1,909 & 3,45 \\
96 & 2,455 & 3,7 \\
97 & 2 & 3,05 \\
98 & 1,182 & 3,08 \\
\hline & &
\end{tabular}

Notes: 2 invalid data

Table 4 has unpaired data and is continuous. Therefore, the data is then tested for correlation using the Spearman correlation test. The results of this test can be seen in Table 5 and the scatterplot of relationship graph can be found in Figure 11.

Table 5 Spearman Correlation Test Result

\begin{tabular}{|c|c|c|}
\hline Spearman's Rho & 0,097961 & Direct, or positive, corelation \\
\hline Degrees of Freedom & 98 & \\
\hline
\end{tabular}

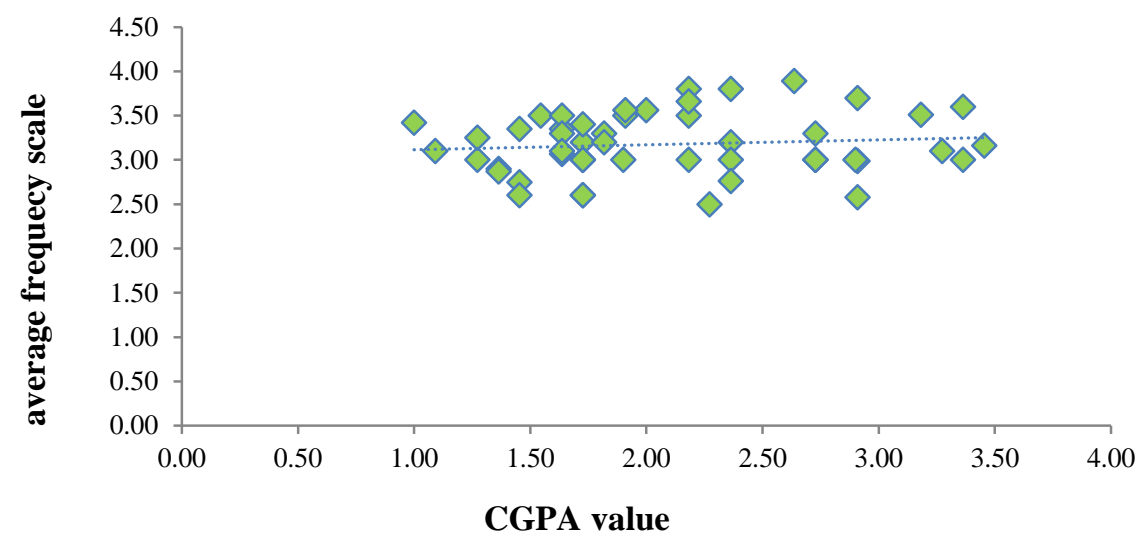

Figure 11 Scatterplot of Relationship between Average Frequency Scale of Social Media Usage and CGPA Value 
The rho value on the Spearmann test ranges from 0-1. The higher the value the greater the correlation between the two variables tested. If the value of rho 0 then there is no relationship at all, whereas if the value rho 1 then there is a very strong relationship. The rho value obtained in this correlation test is 0,098 with positive correlation. This indicates that the value is very weak, not significant and should not be considered or called negligible correlation. However, the value is still qualified to be said to be positively correlated because it falls within the range $0-0,3$ in accordance with the interpretation of Table 6 . This indicates that not necessarily students who often use English when the activity in social media has a good GPA value even though the data show the correlation positive.

Table 6 Rule of Thumb for Interpreting the Size of a Correlation Coefficient based on rho Value

\begin{tabular}{ll}
\hline Size of Correlation & Interpretation \\
\hline $0,90-1,00(-0,90--1,00)$ & Very high positive (negative) correlation \\
$0,70-0,90(-0,70--0,90)$ & High positive (negative) correlation \\
$0,50-0,70(-0,50--0,70)$ & Moderate positive (negative) correlation \\
$0,30-0,50(-0,30--0,50)$ & Low positive (negative) correlation \\
$0,00-0,30(0,00--0,30)$ & Negligible correlation \\
\hline \multicolumn{2}{c}{ Source: Hinkle, Wiersma, \& Jurs (2003) }
\end{tabular}

The results of this test are also in line with the results of research Lubis et al. (2011) that prove there is no significant relationship between the time spent on the use of Facebook with students' CGPA scores. Kay et al. (2014) have also stated that there is not enough evidence to prove that there is a relationship between self-perception in self-perceive English proficiency with the use of social networking sites.

\section{CONCLUSIONS}

Most respondents chose to use social media in the form of social network and video sharing compared to the form of the blog with half more respondent have 3-4 accounts. Youtube delivers the most visited and most influential sites in learning English. Some features of social media, sharing is a facility that is considered to provide the most benefits of learning English. Most respondents prefer to insert English phrases when communicating in social media and feel a lot of learning new vocabulary when using social media. The frequency trend of the questioning that leads to the utilization of various social media features using English shows an average answer of 1-5 times per week. This frequency, in general, shows the habit of respondents using English when interacting with social media. There is a positive correlation but with a very low correlation value (negligible correlation) between the frequency of using English in social media with a student's GPA score. Therefore, it can not be proved significantly that the more often the use of social media with English then the higher the value of a person's GPA.

\section{REFERENCES}

Ashley, J. (2003). Synchronous and asynchronous communication tools. Retrieved on January $1^{\text {st }}$, 2017 from http://www.asaecenter.org /Resources/articledetail.cfm?

Bicen, H., Sadıkoglu, S., \& Sadıkoglu, G. (2014). The impact of social networks on undergraduate students learning foreign language. Procedia - Social and Behavioral Sciences, 186, 10451049 . 
Dalton, J. (2009). Teaching and learning through social networks. Retrieved January 1 ${ }^{\text {st }}, 2017$ from www.teachingenglish.org.uk.print/5411.

Dhanya, G. (2016). Influence of social media on English language learning. Journal of English Language and Literature (JOELL), 3(1).

Hinkle, D. E., Wiersma, W., \& Jurs, S. G. (2003). Applied Statistics for the behavioral sciences $\left(5^{\text {th }}\right.$ Ed.). Boston: Houghton Mifflin.

Kabilan, M. K., Ahmad, N., \& Abidin, M. J. Z. (2010). Facebook: An online environment for learning of English in institutions of higher education? Internet and Higher Education, 13(4), 179-187.

Kalasi, R. (2014). The impact of social networking on new age teaching and learning: An overview. Journal of Education \& Social Policy, 1(1), 23-28.

Kamnoetsin, T. (2014). Social media use: A critical analysis of Facebook's impact on collegiate EFL students' English writing in Thailand. Seton Hall University dissertations and theses (ETDs). Seton Hall University: New Jersey.

Kaplan, A., \& Haenlein, M. (2010). Users of the world, unite! The challenges and opportunities of social media. Business Horizons, 53(1), 59-68.

Kay, C. Y., Kai, F. J., Jun, G. K., \& Hor, W. Y. (2014). The impact of social network on English proficiency among students in University Tunku Abdul Rahman (UTAR), Sungai Long, Malaysia - Final Year Project, UTAR. Retrieved on January $1^{\text {st }}, 2017$ from http://eprints.utar.edu.my/id/eprint/1684.

Kemenkominfo. (2013). Kominfo: Pengguna internet di Indonesia 63 juta orang. Retrieved on January $\quad 7^{\text {th }}, \quad 2017 \quad$ from https://kominfo.go.id/index.php/content/detail/3415/Kominfo+\%3A+Pengguna+ Internet+di+Indonesia+63+Juta+Orang/0/berita_satker.

Li, V. (2017). Social media in English language teaching and learning. International Journal of Learning and Teaching, 3(2), 148-153.

Lubis, S. H., Ridzuan, S., Ishak, I. Y., Othman, H. F., Mohammed, N., Hamida, Z. A., Akmal, N. N., Norazizah., Farahana, N., Shahida., Shanti., Zafiraha, N.N., Hui, L. L., \& Izham, M. (2011). The relationship between time spent on Facebook and cumulative grade point average (CGPA) among third year Biomedical Science students in Faculty Health Sciences, UKM. Procedia Social and Behavioral Sciences Volume 60. Pulau Pinang, Malaysia. pp 590 -595.

Monica-Ariana, S., \& Anamaria-Mirabela, P. (2014). The impact of social media on vocabulary learning case study Facebook. Annals of the University of Oradea, Economic Science Series, 23(2), 120-130.

Nikbakht, E. (2015). Analyzing the potential of social networking sites on EFL learners' vocabulary mastery: A situated-learning approach. Theory and Practice in Language Studies, 5(8), 16351641.

Obar, J. A., \& Wildman, S. (2015). Social media definition and the governace challange: An introduction to the special issue. Telecommunications policy, 39(9), 745-750. 
Peixoto, P., \& Montanher. (2013). EXSTAT - Excel Statistical Calculator, Version 2.0. Retrieved on January $7^{\text {th }}, 2017$ from www.ime.usp.br/ pedrosp.

Sitthirak, C. (2013). Social media for language teaching and learning. Language Institute, Thammasat University.

Statista. (2017). Number of social network users in selected countries in 2016 and 2021 (in millions). Retrieved on July $12^{\text {th }}, 2017$ from https://www.statista.com/statistics/278341/number-ofsocial-network-users-in-selected-countries/.

Suthiwartnarueput, T., \& Wasanasomsithi, P. (2012). Effects of using Facebook as a medium for discussions of English grammar and writing of low-intermediate EFL students. Electronic Journal of Foreign Language Teaching, 9(2), 194-214.

Thurairaj, S., Hoon E. P., Roy S. S. \& Fong P. K. (2015). Reflections of students' language usage in social networking sites: Making or marring academic English. The Electronic Journal of $e$ Learning, 13(4), 302-316.

Wang, C. H., \& Chen, C. P. (2013). Effects of Facebook tutoring on learning English as a second language. International Conference e-Learning 2013, Part of the IADIS Multi Conference on Computer Science and Information System 2013. Czech Republic. pp 135-142.

Wu, H. J., \& Wu, P. L. (2011). Learners' perceptions on the use of blogs for EFL learning. US China Education Review, A(3), 323-330. 


\section{APPENDIX}

Read each question carefully and then give the answer by circling the options provided. This answer will not adversely affect you. Give the honest answer on your own. The author greatly appreciates your participation. thanks.

Gender

Semester

GPA

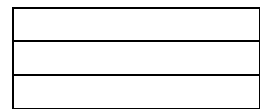

\begin{tabular}{|c|c|c|c|c|c|c|c|c|c|}
\hline PART & $\begin{array}{l}\text { Questions for the use } \\
\text { of social networking }\end{array}$ & \multicolumn{8}{|c|}{ Circle the selected answer (ANSWER MORE THAN ONE) } \\
\hline 1 & $\begin{array}{l}\text { Among the options of } \\
\text { the following social } \\
\text { media sites, which sites } \\
\text { do you have? }\end{array}$ & facebook & twitter & linkedin & youtube & google+ & blogger & wordpress & $\begin{array}{l}\text { tidak } \\
\text { ada }\end{array}$ \\
\hline \multicolumn{2}{|c|}{$\begin{array}{l}* \text { if the answer "no" then no need } \\
\text { to answer the next question. }\end{array}$} & \multicolumn{8}{|c|}{ Circle one of the selected answers (ONLY ONE ANSWER) } \\
\hline 2 & $\begin{array}{l}\text { Which social media } \\
\text { sites that provide the } \\
\text { most impact in English } \\
\text { language acquisition? }\end{array}$ & facebook & twitter & linkedin & youtube & google+ & blogger & wordpress & \\
\hline 3 & $\begin{array}{l}\text { Social media sites are } \\
\text { most frequently } \\
\text { visited? }\end{array}$ & facebook & twitter & linkedin & youtube & google+ & blogger & wordpress & \\
\hline 4 & $\begin{array}{l}\text { What features or } \\
\text { facilities are most } \\
\text { helpful in the process } \\
\text { of obtaining English? }\end{array}$ & profile & friends & comment & sharing & & & & \\
\hline 5 & $\begin{array}{l}\text { Which language } \\
\text { elements are most } \\
\text { commonly used in } \\
\text { social media sites? }\end{array}$ & word & phrase & clause & & & & & \\
\hline 6 & $\begin{array}{l}\text { Which language skills } \\
\text { most benefit when } \\
\text { using social media sites } \\
\text { above? }\end{array}$ & writing & speaking & listening & vocabulary & grammar & reading & & \\
\hline
\end{tabular}

\begin{tabular}{|c|c|c|c|c|c|c|c|}
\hline \multirow[b]{2}{*}{ 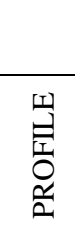 } & \multirow{2}{*}{$\begin{array}{r}\text { PART } \\
\text { B } \\
\\
1 \\
1\end{array}$} & \multirow{2}{*}{$\begin{array}{l}\begin{array}{l}\text { Questions for frequency of using } \\
\text { social networking sites }\end{array} \\
\begin{array}{l}\text { How often do you manage your } \\
\text { personal profile with English words } \\
\text { or phrases? }\end{array}\end{array}$} & \multicolumn{5}{|c|}{ Circle one answer selected (ONLY ONE ANSWER) } \\
\hline & & & $\begin{array}{c}0 \times \text { per } \\
\text { week }\end{array}$ & $\begin{array}{l}1-5 \times \text { per } \\
\text { week }\end{array}$ & $\begin{array}{c}6-10 \times \text { per } \\
\text { week }\end{array}$ & $\begin{array}{c}10-15 \times \text { per } \\
\text { week }\end{array}$ & $\begin{array}{c}>15 \times \text { per } \\
\text { week }\end{array}$ \\
\hline \multirow{3}{*}{ 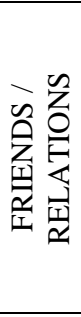 } & 2 & $\begin{array}{l}\text { How often do you add (add) or add } \\
\text { overseas friends who use English } \\
\text { on social networks? }\end{array}$ & $\begin{array}{c}0 \times \text { per } \\
\text { week }\end{array}$ & $\begin{array}{l}1-5 \times \text { per } \\
\text { week }\end{array}$ & $\begin{array}{l}\text { 6-10 } \times \text { per } \\
\text { week }\end{array}$ & $\begin{array}{l}10-15 \times \text { per } \\
\text { week }\end{array}$ & $\begin{array}{l}>15 \times \text { per } \\
\quad \text { week }\end{array}$ \\
\hline & 3 & $\begin{array}{l}\text { How often do you communicate } \\
\text { verbally (video call) with overseas } \\
\text { friends using English? }\end{array}$ & $\begin{array}{c}0 \times \text { per } \\
\text { week }\end{array}$ & $\begin{array}{l}1-5 \times \text { per } \\
\text { week }\end{array}$ & $\begin{array}{c}6-10 \times \text { per } \\
\text { week }\end{array}$ & $\begin{array}{c}10-15 \text { xper } \\
\text { week }\end{array}$ & $\begin{array}{c}>15 \times \text { per } \\
\text { week }\end{array}$ \\
\hline & 4 & $\begin{array}{l}\text { How often do you communicate in } \\
\text { writing (chat or comment) with } \\
\text { overseas friends using English? }\end{array}$ & $\begin{array}{c}0 \times \text { per } \\
\text { week }\end{array}$ & $\begin{array}{l}1-5 \times \text { per } \\
\text { week }\end{array}$ & $\begin{array}{l}6-10 \times \text { per } \\
\text { week }\end{array}$ & $\begin{array}{l}10-15 \times \text { per } \\
\text { week }\end{array}$ & $\begin{array}{l}>15 \times \text { per } \\
\quad \text { week }\end{array}$ \\
\hline \multirow{2}{*}{ 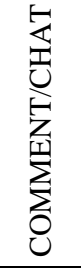 } & 5 & $\begin{array}{l}\text { How often do you use English in a } \\
\text { conversation while chatting or } \\
\text { writing a comment with anyone? }\end{array}$ & $\begin{array}{c}0 \times \text { per } \\
\text { week }\end{array}$ & $\begin{array}{l}1-5 \times \text { per } \\
\text { week }\end{array}$ & $\begin{array}{c}6-10 \times \text { per } \\
\text { week }\end{array}$ & $\begin{array}{c}10-15 \times \text { per } \\
\text { week }\end{array}$ & $\begin{array}{c}>15 \times \text { per } \\
\text { week }\end{array}$ \\
\hline & 6 & $\begin{array}{l}\text { How often do you add English } \\
\text { words in an Indonesian-language } \\
\text { conversation on social networking } \\
\text { sites? }\end{array}$ & $\begin{array}{c}0 \times \text { per } \\
\text { week }\end{array}$ & $\begin{array}{l}1-5 \times \text { per } \\
\text { week }\end{array}$ & $\begin{array}{c}6-10 \times \text { per } \\
\text { week }\end{array}$ & $\begin{array}{c}10-15 \times \text { per } \\
\text { week }\end{array}$ & $\begin{array}{c}>15 \times \text { per } \\
\text { week }\end{array}$ \\
\hline
\end{tabular}




\begin{tabular}{|c|c|c|c|c|c|c|c|}
\hline \multirow{2}{*}{ 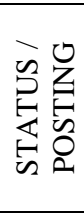 } & 7 & $\begin{array}{l}\text { How often do you write in your } \\
\text { own account (in the form of status, } \\
\text { tweets, notes, etc.) in English? }\end{array}$ & $\begin{array}{c}0 \times \text { per } \\
\text { week }\end{array}$ & $\begin{array}{c}1-5 \times \text { per } \\
\text { week }\end{array}$ & $\begin{array}{c}\text { 6-10 } \times \text { per } \\
\text { week }\end{array}$ & $\begin{array}{c}10-15 \times \text { per } \\
\text { week }\end{array}$ & $\begin{array}{c}>15 \times \text { per } \\
\text { week }\end{array}$ \\
\hline & 8 & $\begin{array}{l}\text { How often do you add English } \\
\text { words in an Indonesian language } \\
\text { status on social media sites? }\end{array}$ & $\begin{array}{c}0 \times \text { per } \\
\text { week }\end{array}$ & $\begin{array}{c}1-5 \times \text { per } \\
\text { week }\end{array}$ & $\begin{array}{c}6-10 \times \text { per } \\
\text { week }\end{array}$ & $\begin{array}{c}10-15 \times \text { per } \\
\text { week }\end{array}$ & $\begin{array}{c}>15 \times \text { per } \\
\text { week }\end{array}$ \\
\hline 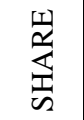 & 9 & $\begin{array}{l}\text { How often do you share things } \\
\text { (news, status, notes etc.) in English } \\
\text { on social media sites? }\end{array}$ & $\begin{array}{c}0 \times \text { per } \\
\text { week }\end{array}$ & $\begin{array}{c}1-5 \times \text { per } \\
\text { week }\end{array}$ & $\begin{array}{c}\text { 6-10 } \times \text { per } \\
\text { week }\end{array}$ & $\begin{array}{c}10-15 \times \text { per } \\
\text { week }\end{array}$ & $\begin{array}{c}>15 \times \text { per } \\
\text { week }\end{array}$ \\
\hline 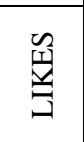 & 10 & $\begin{array}{l}\text { How often do you like things about } \\
\text { English course instructions / } \\
\text { courses / methods on social media } \\
\text { sites? }\end{array}$ & $\begin{array}{c}0 \times \text { per } \\
\text { week }\end{array}$ & $\begin{array}{c}1-5 \times \text { per } \\
\text { week }\end{array}$ & $\begin{array}{c}\text { 6-10 } \times \text { per } \\
\text { week }\end{array}$ & $\begin{array}{c}10-15 \times \text { per } \\
\text { week }\end{array}$ & $\begin{array}{c}>15 \times \text { per } \\
\text { week }\end{array}$ \\
\hline 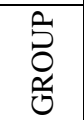 & 11 & $\begin{array}{l}\text { How often do you follow groups / } \\
\text { discussion groups that use or learn } \\
\text { English on social media sites? }\end{array}$ & $\begin{array}{c}0 \times \text { per } \\
\text { week }\end{array}$ & $\begin{array}{c}1-5 \times \text { per } \\
\text { week }\end{array}$ & $\begin{array}{c}\text { 6-10 } \times \text { per } \\
\text { week }\end{array}$ & $\begin{array}{c}10-15 \times \text { per } \\
\text { week }\end{array}$ & $\begin{array}{c}>15 \times \text { per } \\
\quad \text { week }\end{array}$ \\
\hline
\end{tabular}

